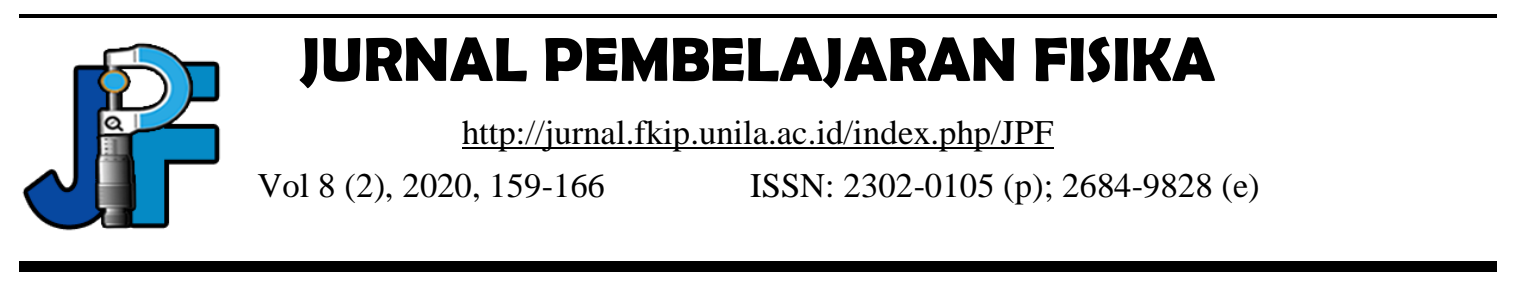

\title{
The Role of Social Media in Learning Physics: Teacher and Student Perceptions
}

\author{
Rika Dwi Kurniati, Doni Andra*, I Wayan Distrik \\ Master of Physics Education FKIP University of Lampung, Indonesia \\ *e-mail: doniandra.fisika10@gmail.com
}

\begin{abstract}
This study aims to determine the role of social media in learning. We know that today, social media has an indispensable role in the learning process. In addition, social media has made it a smaller world through social media so that people from anywhere in the world can interact without being limited by distance and time. This study used a mixed method consisting of qualitative and quantitative data. This research involved 308 students in Lampung province. The results of the research conducted stated that $65 \%$ of students used smartphones in learning. $73.2 \%$ of students stated that the application that is often opened is social media. $87.2 \%$ stated that the most frequently accessed social media is chatting media. $48.2 \%$ of students prefer playing on social media than learning physics. $72.3 \%$ of students stated that they prefer to discuss through chatting media. Based on the results of the preliminary study, the role of social media is very active, $48 \%$ of students stated that they use social media for learning discussions. . $43 \%$ of teachers stated that they always use social media to support learning.
\end{abstract}

Keywords: social media, physics learning, smartphone

DOI: http://dx.doi.org/10.23960/jpf.v8.n2.202004 


\section{INTRODUCTION}

In the modern era, social media and social networks drastically influence human behavior, and technology has become a daily part of people's lives in modern times like today (Raghavendra, 2018). Innovations are taking place rapidly in the field of information technology, one of which is social media and networking sites. For example, Facebook, LinkedIn, Twitter, and WhatsApp provide a new model of social interaction communication patterns (Sapountzi, 2018). So, social media refers to computer technology intermediaries facilitating the growth and sharing of ideas, awareness, career interests, information, and other methods of expression through social networks and virtual communities (Nielsen, 2017). The content generated by social media users, such as comments, posts, digital photos, video sharing, and all online interaction data, is very important and represents the lifeblood of social networks and social media sites (Russell, 2016). Social media users usually access social media services via a laptop or mobile device connected to the internet (Shepherd, 2018). Students can interact with each other to share ideas, express opinions, modify, and discuss material, this is one of the impacts of technological innovation (Birim, 2016).

Technological innovation has resulted in both positive and negative changes in the discussion of culture and society. The influence of social media and social networking sites has a significant impact on students during their transition to adulthood (Zhu, 2017). One of the constructive impacts of using social media is the public's introduction to usergenerated data, ideas, and programming at a relatively young age, which has encouraged additional technological advances and increased knowledge in the student community (Intravia, 2017). However, the spread of social media has also increased depression in students and drastically changed the social atmosphere in which students thrive and learn.

The influence of technology on education has fostered network-based learning to facilitate collaboration regardless of distance (Mariki, 2013); (Rahman, 2014). The social network uses the media, one of which is a smartphone. The results of a survey conducted by researchers on high school students in Lampung Province stated that the intensity ofuse for smartphone more than 6 hours per day reached $47.6 \%$, the time span forusage smartphone the most intensewas at $19.00-21.00$ which was $72.8 \%$ which should have been This time is used by students to learn independently to do assignments. as much as $73.2 \%$ of students opened social media applications.

Social media offers modern and creative ways to build a social learning environment (Abdelraheem \& Ahmed, 2018). Social media applications in the form of discussion groups can trigger and increase interactions between instructors and students (Alabdulkareem, 2015; Barhoumi, 2015; Naidoo \& Kopung, 2016; Prescott et al., 2013; Rambe \& Bere, 2013; Sobaih, 2016). By using social media this supports the change from teacher-centered learning to student-centered (Mihaela and Magdalena 2017) and also improves student self-regulation (Herawati, 2017); (YotDomínguez \& Marcelo, 2017). In line with Amry's research (2014) states that learning usingaccess chat can support an active learning process. The benefit of implementinglearning mobile is that it provides a forum for students to discuss with each other and expand the learning environment anywhere and anytime (Crescente \& Lee, 2011).

This study aims to determine how social media is related to student learning behavior. The study investigates social media use, viewpoints, opinions of interests, 
media use issues, and other respondents' concerns. This study illustrates the effect of increasing access to information and social media on 831 respondents from different regions of Pakistan, including issues related to the structure and use of social networks, social respondents reason. using social media, and how respondents see the positive and negative aspects of networking sites.

\section{METHOD}

\section{Research Design \& Procedures}

This research uses mixed methods, consisting of qualitative data and quantitative data. The sampling technique was carried out by purposive sampling

\section{Population and Sample.}

Data collection was carried out by giving questionnaires to 308 high school students and 15 teachers in Lampung province.

\section{Data Collection and Instrument}

Instruments used a Likert scale with four options, namely (1) strongly agree, (2) agree, (3) do not agree, (4) strongly disagree (Budiyono, 2017) The assessment instrument is provided in the form of a google form.

\section{Data Analysis}

The results of the respondents' assessment were analyzed by calculating the average score obtained for each component, then converted to a qualitative statement according to Table

Table 1. Assessment and Decision

\begin{tabular}{cc}
\hline Score Average Score & Decision \\
\hline $4.20-5.00$ & Very suitable \\
$3.40-4.19$ & Suitable \\
$2.60-3.39$ & Sufficiently suitable \\
$1.80-2.59$ & Less suitable \\
$1.00-1,79$ & Not according to \\
\hline
\end{tabular}

\section{RESULT AND DISCUSSION}

Preliminary research results based on needs analysis were obtained from the google form filled in by physics teachers and students can be seen in Table 2 and table 
Table 2. Results of Student Needs Analysis

\begin{tabular}{clc}
\hline NO & \multicolumn{1}{c}{ Statement for Student } & $\begin{array}{c}\text { Percentag } \\
\text { e }\end{array}$ \\
\hline 1 & I like learning physics & $65 \%$ \\
2 & I prefer to play social media than learning physics & $48.5 \%$ \\
3 & Since junior high school already has a smartphone & $51.9 \%$ \\
4 & The intensity of smartphone use every day is more than 6 hours & $48.2 \%$ \\
5 & The time span for the most intense smartphone usage is 19.00- & $46.6 \%$ \\
& 21.00 & $65 \%$ \\
6 & Always use a smartphone for learning & $93.5 \%$ \\
7 & teacher gives students the opportunity to find information with & \\
& their friends when discussing & $48 \%$ \\
8 & teacher uses social media assistance to discuss in learning & $100 \%$ \\
9 & Teachers give students the opportunity to find other sources & $87 \%$ \\
10 & Teachers give students the opportunity to solve problems in their & \\
& own way & $53.8 \%$ \\
11 & Teachers give students the opportunity to experiment & $59.2 \%$ \\
12 & Teachers give students opportunities students to present & \\
& experimental results & $73,2 \%$ \\
13 & Social media applications that are often on smartphones & $41.5 \%$ \\
14 & Social media that is frequently opened is the media chat & $87.2 \%$ \\
15 & most frequently opened chat media is WhatsApp & $32 \%$ \\
16 & One of your choices during UNBK is physics lessons & $72,3 \%$ \\
17 & Prefer the learning process using social media &
\end{tabular}

This study aims to determine the role of social media in learning. $65 \%$ of high school students in Lampung province, consisting of 308 respondents, stated that they always use smartphones in learning. From table 2 it can be seen that $51.9 \%$ of students have owned smartphones since junior high school (SMP). $48.2 \%$ of students intensity use smartphones more than 6 hours a day. As many as $46.6 \%$ of students use it at night which should be used for studying or doing assignments. $73.2 \%$ of students stated that the most frequently opened application is social media. $87.2 \%$ stated that the most frequently accessed social media is chatting media. $48.2 \%$ of students prefer playing on social media than learning physics. Students find it difficult when learning physics, this is evidenced by when UNBK only $32 \%$ of students chose physics lessons to be tested. $81.4 \%$ of respondents stated that it was very difficult to learn physics material. due to several factors such as teachers only giving assignments without being given an explanation, difficulties in doing assignments, too many assignments, constraints on quotas and internet networks, no teaching materials such as modules to make it easier for students in learning and so on, so that learning becomes less effective. Therefore, researchers recommend social media assisted learning in the learning process so that students don't feel bored. In addition, students and teachers can interact and share information without being limited by distance and time. 
Table 3. Results of Teacher Needs Analysis

\begin{tabular}{|c|c|c|}
\hline NO & Statement for Teachers & Percentage \\
\hline 1 & I do online and offline learning & $100 \%$ \\
\hline 2 & I use social media more in learning & $25.8 \%$ \\
\hline 3 & On average my students have smartphones & $82.5 \%$ \\
\hline 4 & The intensity of smartphone use every day is more than 6 hours & $37.2 \%$ \\
\hline 5 & $\begin{array}{l}\text { The time span for the most intense smartphone usage is } 19.00 \text { - } \\
21.00\end{array}$ & $57.6 \%$ \\
\hline 6 & Always use a smartphone for learning & $43 \%$ \\
\hline 7 & $\begin{array}{l}\text { Teachers give students the opportunity to find information with } \\
\text { friends when discussing }\end{array}$ & $98 \%$ \\
\hline 8 & Teachers use social media assistance to discuss in learning & $58 \%$ \\
\hline 9 & Teachers give students the opportunity to find other sources & $100 \%$ \\
\hline 10 & $\begin{array}{l}\text { Teachers give students the opportunity to solve problems in their } \\
\text { own way }\end{array}$ & $93 \%$ \\
\hline 11 & Teachers give students the opportunity to experiment & $43.2 \%$ \\
\hline 12 & $\begin{array}{l}\text { Teachers give students opportunities students to present the results } \\
\text { of the experiment }\end{array}$ & $70.2 \%$ \\
\hline 13 & Social media applications that are often in smar cellphone & $75.2 \%$ \\
\hline 14 & Social media that is frequently opened is the media chat & $51.3 \%$ \\
\hline 15 & The most frequently opened chat media is WhatsApp & $90.2 \%$ \\
\hline 16 & One of your choices when UNBK is physics lessons & $22 \%$ \\
\hline 17 & Prefer the learning process using social media & $43 \%$ \\
\hline
\end{tabular}

From table $3100 \%$ of teachers say they use online and offline learning. Only $25.8 \%$ of teachers use social media in learning. $100 \%$ of teachers stated that it provides opportunities for students to seek various information. Only $22 \%$ of the total students took physics at UNBK. The difficulty of the teacher when teaching physics using social media when the material is arithmetic, students find it difficult to understand.

This is in line with research by Stathopoulou et al. (2019) revealed that including social media in education has a positive impact on learning. Social media is a means of support for students during the learning process, and is also useful for educators. The 
study's findings reveal that social media has both positive and negative impacts on student learning (Lee, 2017). The results of the study by Balakrishnan and Gan (2016) show that there is a positive impact on student achievement and motivation. Another study revealed that learning using social media makes it easier for teachers to cope with different student learning styles (Law, 2019). whereas social media has a broader effect on students in the classroom (Kaufer, 2011).

\section{CONCLUSION}

Based on research data regarding the role of social media in learning, it can be concluded that based on the results of a preliminary study, the role of social media is very active, $48 \%$ of students stated that they use social media for learning discussions. $43 \%$ of teachers stated that they always use social media to support learning.

\section{ACKNOWLEDGEMENTS (OPTIONAL)}

Thank you to the Directorate of Research and Community Service (DRPM) for funding this research through the Master Thesis Research (PTM) Scheme and the Board for Research and Community Service (LPPM) Lampung University which has Provided facilities.

\section{REFERENCES}

Raghavendra, P .; Hutchinson, C .; Grace, E .; Wood, D .; Newman, L. "I like talking to people on the computer": Outcomes of a home-based intervention to develop social media skills in youth with disabilities living in rural communities. Res. Dev. Disabil. 2018, 76, 110-123.

Sapountzis, A .; Engineer, KE Social networking data analysis tools \& challenges. Future Gener. Comput. Syst. 2018, 86, 893-913.

Nielsen, MISW Computer-mediated communication and self-awareness - A selective review. Comput. Hum. Behav. 2017, 76, 554-560.

Russell, BS; Maksut, JL; Lincoln, CR; Leland, AJ Computer-mediated parenting education: Digital family service provision. Child. Youth Serv. Rev. 2016, 62, 18.

Shepherd, SV; Freiwald, WA Functional Networks for Social Communication in the Macaque Monkey. Neurons 2018, 99, 413-420.e3.

Birim, B. Evaluation of Corporate Social Responsibility and Social Media as Key Source of Strategic Communication. Procedia Soc. Behav. Sci. 2016, 235, 70-75.

Zhu, L .; Anagondahalli, D .; Zhang, A. Social media and culture in crisis communication: McDonald's and KFC crises management in China. Public Relat. Rev. 2017, 43, 487-492.

Intravia, J .; Wolff, KT; Paez, R .; Gibbs, BR Investigating the relationship between social media consumption and fear of crime: A partial analysis of mostly young adults. Comput. Hum. Behav. 2017, 77, 158-168. 
Budiyono 2017 Introduction to Educational Research Methodology ed Sudiyanto (Surakarta: UNS PRESS)

Rambe, P. and Bere, A. 2013. Using mobile instant messaging to leverage learner participation and transform pedagogy at a south African university of technology. J. Educational Technology, 44 (4), 1 - 6

Yot-Domínguez, Carmen, and Carlos Marcelo. 2017. University Students' Self-Regulated Learning Using Digital Technologies. International Journal of Educational Technology in Higher Education, 14 (1)

Abdelraheem, AY, \& Ahmed, AM (2018). The impact of using Mobile Social Network Applications on Students' Social-Life. International Journal of Instruction, 11 (2), $1-14$.

Alabdulkareem, SA (2015). Exploring the use and the impacts of social media on teaching and learning science in Saudi. Procedia-Social and Behavioral Sciences, 182, 213224.

Amry, AB (2014). The impact of WhatsApp mobile social learning on the achievement and attitudes of female students compared with face to face learning in the classroom. European Scientific Journal, ESJ, 10 (22), 116-136.

Crescente, ML, \& Lee, D. (2011). Critical issues of m-learning: design models, adoption processes, and future trends. Journal of the Chinese Institute of Industrial Engineers, 28 (2), 111-123.

Herawati, NT 2017. The Implementation of Self-Regulated Learning Model Using ICT Media Toward the Students Achievement in Introduction to Accounting Course. Journal of Accounting and Business Education, 2 (1), 144-157.

Mihaela, Paisi Lăzărescu, \& Stan Maria Magdalena. 2017. "Student Centered Learning Using ICT." Pp. 1-4 in Proceedings of the 9th International Conference on Electronics, Computers and Artificial Intelligence, ECAI 2017

Rambe, P. and Bere, A. 2013. Using mobile instant messaging to leverage learner participation and transform pedagogy at a south African university of technology. J. Educational Technology, 44 (4), 1 - 6

Stathopoulou, A .; Siamagka, N.-T .; Christodoulides, G. A multi-stakeholder view of social media as a supporting tool in higher education: An educator-student perspective. Eur. Manag. J. 2019, in press.

Lee, AR; Suzanne Horsley, J. The role of social media on positive youth development: An analysis of the 4-H Facebook page and 4-H'ers' positive development. Child. Youth Serv. Rev. 2017, 77, 127-138.

Balakrishnan, V .; Gan, CL Students' learning styles and their effects on the use of social media technology for learning. Telematous. Inform. 2016, 33, 808-821.

Law, KMY; Gang, S .; Li, T. Student enrollment, motivation and learning performance in a blended learning environment: The mediating effects of social, teaching, and cognitive presence. Comput. Educ. 2019, 136, 1-12. 
Kaufer, D .; Gunawardena, A .; Tan, A .; Cheek, A. Bringing social media to the writing classroom: Classroom salon. J. Bus. Tech. Commun. 2011, 25, 299-321. 